\title{
Accelerated Aging in Tomato Seeds
}

\author{
Andreia da Silva Almeida, Cristiane Deuner, Carolina Terra Borges, \\ Geri Eduardo Meneghello, Lilian Madruga de Tunes, Francisco Amaral Villela \\ Programa de Pós-Graduação em Ciência e Tecnologia de Sementes, Universidade Federal de Pelotas, Pelotas, \\ Brasil \\ Email: andreiasalmeida@yahoo.com.br
}

Received 29 March 2014; revised 28 April 2014; accepted 8 May 2014

Copyright (C) 2014 by authors and Scientific Research Publishing Inc.

This work is licensed under the Creative Commons Attribution International License (CC BY). http://creativecommons.org/licenses/by/4.0/

(c) (i) Open Access

\begin{abstract}
The tomato plant (Lycopersicum esculentum L.) is a perennial, shrubby-like vegetable with high reproductive ability, which behaves like a typical annual crop. The aim of this work was to select suitable tests to assess the quality of different lots of tomato seeds. Six batches of tomato seeds were assessed for parameter values: moisture content, germination, first count, accelerated aging (standard: $40 \mathrm{~mL}$ of water; saline solution: $11 \mathrm{~g} \mathrm{NaCl} / 100 \mathrm{~mL}$ of water and saturated saline solution: $40 \mathrm{~g} \mathrm{NaCl} / 100 \mathrm{~mL}$ water) and seedling emergence in soil. Accelerated aging through the use of saturated salt solution for $48 \mathrm{~h}$ or $72 \mathrm{~h}$ at $41^{\circ} \mathrm{C}$ resulted in an alternative and efficient way to evaluate the physiological quality of tomato seeds. The standard accelerated aging test was less efficient and exhibited higher moisture variation.
\end{abstract}

\section{Keywords}

\section{Lycopersicum esculentum, Germination, Vigor, Physiological Quality}

\section{Introduction}

The tomato plant (Lycopersicum esculentum L.) belongs to the Solanaceae family, exhibiting a shrub-like habit with a growth cycle typical of annual plants. The species originated in the Andes region, and was introduced to Brazil by European immigrants at the end of the XIX century. Its morphology is that of a creeping plant with semi-erect and erect forms, which exhibit specific thermal requirements for flowering [1].

In recent years, the Brazilian production of vegetable seeds has increased its demand for better quality products, thus significantly influencing production systems. Despite this progress, much remains to be done not only to achieve self-sufficiency but also to produce top quality seed, especially in regard to germination uniformity that will guarantee adequate stands. Within this context, producing and delivering high vigor vegetable seeds constitute basic and fundamental elements to keep this industry’s growth. However, given this trend, the need 
for improvement on the existing seed quality tests used to detect subtle variations among seed lots is necessary [2] [3].

Vigor tests are effective complementary tools to the information provided by the germination test, and are directly related to seed performance in the field and during storage. Knowledge of seed vigor enables the production of seedlings of uniform size and growth rate, with advantages to the crop's development [4].

Seed quality is routinely assessed through the germination test, which has been certified as the result of its reproducibility [5] [6]. Under the environment in which the germination test is performed, seed germination is enhanced to the maximum threshold level, conditions rarely found in the field, which account for the discrepancies found on the final values for the performance of a specific seed lot under both situations [7].

The first germination count, usually performed to facilitate the execution of the test is considered a test for vigor, since it is known that the onset of the seed decay process affects the germination speed first rather than the final germination values. Therefore, samples that germinate faster, with higher values for the first count, can be considered more vigorous than those of slower germination [7] [8]. Additionally, this test has the advantage of being of easy implementation and providing results rapidly, but according to [6] [7], it is not able to detect small differences between seed lots due to its low sensitivity.

The accelerated aging test, initially developed to estimate the storage potential of seeds, has proved a very efficient resource to assess seed vigor, thus sorting seed lots according to their ability to germinate and establish in the field. In this test, the rate of seed deterioration is accelerated by their exposure to high levels of temperature and relative humidity [9]. An alternative accelerated aging test method for small-seeded species is under consideration, namely the replacement of water by a saturated salt solution [10]. This work aimed at the assessment of different versions of the accelerated aging test on tomato seed quality.

\section{Materials and Methods}

This research was conducted at the Seed Testing Laboratory from the Plant Science Department, Faculty of Agronomy "Eliseu Maciel”, from the Federal University of Pelotas, at Pelotas, RS.

Tomato seeds originating from five different lots, cultivate Santa Clara were tested for the following traits:

Moisture content: Two four-gram seed sample replicates per lot were put in the oven at $105^{\circ} \mathrm{C} \pm 3^{\circ} \mathrm{C}$ for 24 hours, according to the procedure established by the Regraspara Análise de Sementes-RAS [11], and the resulting values expressed on a percentage basis. Following the different versions of the accelerated aging test, further moisture content tests were performed under the same methodology.

Germination: Four 50-seed sub samples per lot were allocated in plastic germination boxes, over a double layer of blotting paper moistened with water at the equivalent of 2.5 times the weight of paper. Normal seedling counts were performed on the fifth and fourteenth days after being placed in the germination chamber, proceeding in compliance with the Rules for Seed Testing (Regraspara Análise de Sementes) [11].

First germination count: This determination assessed the number of normal tomato seedlings on the fifth day after entering the germination chamber, with results expressed on a percentage basis.

Seedling emergence: Five 50-seed replicates per seed lot were allocated to individual cells in polystyrene trays filled with commercial susbstrate Plantmax ${ }^{\circledR}$ and placed inside a greenhouse. After a 14-day period, seedlings with lengths equal or above $1.0 \mathrm{~cm}$ were counted and the results expressed as percentage of seedling emergence for each replicate.

The three variants for the accelerated aging test assessed in this work were aimed at determining the best alternative, as well as the optimum time of exposure for the seeds being treated.

Standard Accelerated Aging Test (SAAT): This test is based on a $4 \mathrm{~g}$ seed sample laid on a suspended wire mesh and placed in plastic germination boxes, filled with $40 \mathrm{~mL}$ distilled water. All germination boxes were then placed into a B.O.D. incubator a at set temperature of $41^{\circ} \mathrm{C}$ for two distinct periods, $48 \mathrm{~h}$ and $72 \mathrm{~h}$ after which they were subjected to germination tests, as described previously. Five days after entering the germination chamber the first count was performed, and the results computed as the percentage of normal seedlings. According to the procedure described by [12], the moisture content of seeds was estimated for all samples across both accelerated aging periods, at the end of each exposure time.

Saturated Salt Accelerated Aging (SatSAA): This test is performed in a similar fashion to the SAAT (same temperature and exposure time), however, instead of distilled water $40 \mathrm{~mL} \mathrm{NaCl}$ saturated solution ( $40 \mathrm{~g} \mathrm{NaCl}$ in $100 \mathrm{~mL}$ water) are added. Thus, the test is performed under an environment with $76 \%$ relative humidity, as 
described by [13].

Salt Solution Accelerated Aging (SSAA): This variant resulted from an adaptation of the methodology described by [13], the basic difference with the SatSAA method being the $\mathrm{NaCl}$ concentration, in this case $11 \mathrm{~g}$ $\mathrm{NaCl}$ in $100 \mathrm{~mL}$ water. The latter renders an environment with 94\% relative humidity, as estimated by the Van’t Holf equation, as described by [14].

A completely randomized experimental design with four replicates was used to allocate all samples within each test. All data were subjected to analysis of variance and, when appropriate, sample means were compared through the Tukey test to the 5\% significance level. To further test for differences between treatments, the Pearson simple correlation test was run to the $5 \%$ and $1 \%$ probability levels, to compare the data from the different accelerated aging tests with data from the initial seed quality levels.

\section{Results and Discussion}

The initial seed moisture content did not differ across the five seed lots considered in this work (Table 1), varying between $6.3 \%$ and $7.7 \%$. This was appropriate for the execution of the different tests, as uniform seed moisture content is essential to standardization of all procedures to ensure the consistency of results [12].

Under SAAT all seed lots exhibited differences on the moisture content, varying from $12.3 \%$ to $19.5 \%$, however, in SatSAA the variation range was $8.7 \%$ to $9.8 \%$ and under SSAA the highest difference was $1 \%$ and the seeds exhibited moisture contents between $8.7 \%$ and $10.1 \%$, according to the specific lot. These results allow considering the use of a salt solution to control water absorption by seeds, thus aiding on the evaluation of seed vigor from the different lots used in this study. According to [12], the seed moisture content immediately after SSAA is lower and more uniform, a prerequisite to achieve accurate results.

The percentage germination for the different seed lots were similar across all the accelerated aging tests, as shown on Table 2, with values in excess of $90 \%$. This test was efficient to identify seed vigor differences among lots, separating lots 3 and 4 as those of highest quality, lots 1 and 2 as intermediary and lot 5 as the one with the lowest seed quality. However, it must be remembered that despite the first count being an indicator of seed vigor, reductions on the speed of germination are not the first recognizable effects of the seed deterioration process [15].

\section{Table 1. Water content (\%) at commencement and end of SAAT, SSAA and SatSAA periods for five lots of tomato seeds.}

\begin{tabular}{|c|c|c|c|c|c|c|c|}
\hline \multicolumn{8}{|c|}{ MOISTURE LEVELS } \\
\hline \multirow[t]{2}{*}{ Lot } & \multirow[t]{2}{*}{ Moisture \% before Accelerated Aging Test } & \multicolumn{2}{|c|}{ SAAT } & \multicolumn{2}{|c|}{ SSAA } & \multicolumn{2}{|c|}{ SatSAA } \\
\hline & & $48 \mathrm{~h}$ & $72 \mathrm{~h}$ & $48 \mathrm{~h}$ & $72 \mathrm{~h}$ & $48 \mathrm{~h}$ & $72 \mathrm{~h}$ \\
\hline 1 & 7.1 & 12.3 & 18.1 & 11.4 & 12.1 & 8.9 & 9.2 \\
\hline 2 & 7.0 & 18.8 & 19.6 & 12.0 & 13.1 & 8.7 & 8.9 \\
\hline 3 & 6.5 & 17.0 & 19.3 & 10.0 & 11.2 & 8.7 & 9.1 \\
\hline 4 & 6.4 & 19.5 & 21.6 & 11.9 & 12.7 & 9.5 & 9.6 \\
\hline 5 & 7.7 & 15.6 & 16.4 & 12.0 & 14.6 & 9.8 & 10.1 \\
\hline
\end{tabular}

Table 2. Mean values for percentage germination (GERM) and first germination count (CONT 1st.).

\begin{tabular}{|c|c|c|c|}
\hline Lotes & GERM (\%) & $1^{\mathrm{a}} \mathrm{CONT}(\%)$ & EP (\%) \\
\hline 1 & $95 \mathrm{a}$ & $83 \mathrm{~b}$ & $89 \mathrm{c}$ \\
\hline 2 & $94 \mathrm{a}$ & $81 \mathrm{c}$ & $93 \mathrm{ab}$ \\
\hline 3 & $97 \mathrm{a}$ & $93 \mathrm{a}$ & $93 \mathrm{~b}$ \\
\hline 4 & $97 \mathrm{a}$ & $94 \mathrm{a}$ & $95 \mathrm{a}$ \\
\hline 5 & $96 \mathrm{a}$ & $75 \mathrm{~d}$ & $64 \mathrm{~d}$ \\
\hline CV (\%) & 1.56 & 1.13 & 1.09 \\
\hline
\end{tabular}

Means followed by the same letter in columns do not differ by the Tukey test at $5 \%$ probability level. 
The test for seedling emergence (Table 2) also contributed to separate levels of vigor, with lots 2 and 4 showing the highest vigor values and lot 5 the lowest, which indicates this test as an accurate parameter to estimate seed lot quality [15]. All seed lots clearly showed similar high germination values, however, with differences in vigor, making it necessary to develop methodologies capable of rapidly ranking seed lots on this trait.

The sensitivity of the SAAT (100\% RH) and SSAA (94\% RH) (Table 3) tests for classifying seed lots in response to the exposure time was variable, establishing five levels of seed vigor for the period of $48 \mathrm{~h}$ and four levels of vigor for the $72 \mathrm{~h}$ period. The longest exposure period ranked seed lot 1 as the best and seed lot 3 as the worst, and according to [16], the use of a $\mathrm{NaCl}$ solution proved appropriate to assess the quality of radish seeds. Similar results for onion seeds were reported by [17], and for SatSAA (76\% RH), exposure for a $48 \mathrm{~h}$ period was the most adequate, saving time for the acquisition of seed quality data.

Both exposure periods assessed in this work ranked seed lots under three vigor levels, with different responses according to seed lots and time of exposure. Under the shorter exposure time (48 h), seed lots 1 and 4 had the highest values while for the $72 \mathrm{~h}$ period seeds from lots 1 and 2 yielded the best results; lot 5 ranked the lowest under both exposure periods.

When comparing data of SatSAA for the $48 \mathrm{~h}$ period with data from seedling emergence, seed lots 1 and 4 confirmed the highest vigor values, while lot 5 the lowest. This procedure has been reported as the most accurate for comparisons among cabbage and broccoli seed lots by [18], and for okra by [19]. According to [20], exposure of eggplant, broccoli and tomato seeds to SAAT for $48 \mathrm{~h}$ or $72 \mathrm{~h}$ did not result in sharp reductions of seed quality.

The analysis of the correlation coefficients (Table 4) enabled the determination of which of these could be used as predictors of tomato seed quality. Positive correlations to the $5 \%$ probability level could be established between seedling emergence in the greenhouse and the SAAT and SSAA tests, and to the $1 \%$ significance level for the SatSAA test, in both cases for the 48-hour exposure time.

The correlation coefficient between the first count test and SSAA- $48 \mathrm{~h}$ also resulted in a significant difference to the $1 \%$ level, results in agreement with the findings of [17] for coriander seeds. Data obtained for the correlation coefficients between germination and SAAT- $72 \mathrm{~h}$ were significant to the $1 \%$ level, while correlations with greenhouse seedling emergence values tested significant at the $5 \%$ level for the same exposure time. The SSAA-72 h test was a simple and efficient procedure to detect differences among tomato seed lots, reducing laboratory expenses while maintaining quality standards, most probably due to the moisture restrictions that occur during the execution of this test [21] The SatSAA for both $48 \mathrm{~h}$ and $72 \mathrm{~h}$ exposure periods showed correlation with vigor tests. These results are in agreement with the findings of [22] [23] in seeds of lettuce and chicory.

Programs of seed quality control seek fast and efficient methodological alternatives to assess vigor of seed lots, and accelerated aging with a $\mathrm{NaCl}$ saturated solution proved an effective test to rank tomato seed lots, correlating well with seedling emergence values.

\section{Conclusions}

The accelerated aging test conducted with a saturated salt solution for periods of $48 \mathrm{~h}$ or $72 \mathrm{~h}$ at $41^{\circ} \mathrm{C}$ is an

Table 3. Values for the Standard Accelerated Aging Test (SAAT), Salt Solution Accelerated Aging (SSAA) and Saturated Salt Accelerated Aging (SatSAA) from five different tomato seed lots.

\begin{tabular}{|c|c|c|c|c|c|c|}
\hline \multirow{2}{*}{ Lots } & \multicolumn{2}{|c|}{ SAAT (\%) } & \multicolumn{2}{|c|}{ SSAA (\%) } & \multicolumn{2}{|c|}{ SatSAA (\%) } \\
\hline & $48 \mathrm{~h}$ & $72 \mathrm{~h}$ & $48 \mathrm{~h}$ & $72 \mathrm{~h}$ & $48 \mathrm{~h}$ & $72 \mathrm{~h}$ \\
\hline 1 & $81 \mathrm{~b}$ & $71 \mathrm{~b}$ & 98 a & 89 a & $91 \mathrm{~b}$ & $93 \mathrm{a}$ \\
\hline 2 & 85 a & 79 a & $91 \mathrm{c}$ & $80 \mathrm{~b}$ & 93 a & $93 \mathrm{a}$ \\
\hline 3 & $71 \mathrm{c}$ & $64 \mathrm{c}$ & 75 e & $60 \mathrm{~d}$ & $91 \mathrm{~b}$ & $89 \mathrm{~b}$ \\
\hline 4 & $83 \mathrm{~b}$ & $56 \mathrm{~d}$ & $94 \mathrm{~b}$ & $81 b$ & $94 \mathrm{a}$ & $89 \mathrm{~b}$ \\
\hline 5 & $72 \mathrm{c}$ & $54 \mathrm{e}$ & $77 \mathrm{~d}$ & $63 c$ & $88 \mathrm{c}$ & $70 \mathrm{c}$ \\
\hline CV (\%) & 1.08 & 1 & 0.79 & 1.25 & 0.66 & 0.89 \\
\hline
\end{tabular}

Column means followed by the same letter do not differ by the Tukey test at the $5 \%$ probability level. 
Table 4. Pearson correlation coefficients (r) between germination test data (Gem), first germination count (1st.count) and seedling emergence (SE), with Standard Accelerated Aging Test (SAAT), Salt Solution Accelerated Aging (SSAA) and Saturated Salt Accelerated Aging (SatSAA) for tomato seeds exposed for $48 \mathrm{~h}$ or $72 \mathrm{~h}$ to the different accelerated aging treatments.

\begin{tabular}{|c|c|c|c|c|}
\hline & & Gem & 1st.count & $\mathrm{SE}$ \\
\hline \multirow{3}{*}{$48 \mathrm{~h}$} & SAAT & $-0.401^{\mathrm{ns}}$ & $0.069^{\mathrm{ns}}$ & $0.548^{* * *}$ \\
\hline & SSAA & $-0.373^{\text {ns }}$ & $0.126^{\text {ns }}$ & $0.466^{* *}$ \\
\hline & SatSAA & $-0.069^{\mathrm{ns}}$ & $0.616^{*}$ & $0.872^{*}$ \\
\hline \multirow{3}{*}{$72 \mathrm{~h}$} & SAAT & $-0.580^{*}$ & $-0.135^{\mathrm{ns}}$ & $0.477^{* *}$ \\
\hline & SSAA & $-0.387^{\mathrm{ns}}$ & $0.051^{\mathrm{ns}}$ & $0.423^{\mathrm{ns}}$ \\
\hline & SatSAA & $-0.260^{\mathrm{ns}}$ & $0.553^{* *}$ & $0.919^{*}$ \\
\hline
\end{tabular}

* Significant to the $5 \%$ probability level; ${ }^{* *}$ Significant at $1 \%$ probability level and ns not significant.

alternative and efficient method to evaluate the physiological quality of tomato seeds.

The standard accelerated aging test was the least efficient alternative with the highest moisture content variation.

\section{References}

[1] Filgueira, F.A.R. (2003) Novo Manual de Olericultura: Agrotecnologia moderna na produção e comercialização de hortaliças. UFV, Viçosa, 402p.

[2] Mendonça, E.A.F., Ramos, N.P. and Fessel, S.A. (2003) Adequação da metodologia do teste de deterioração controlada para sementes de brócolis (Brassica oleracea L). Revista Brasileira de Sementes, 25, 18-24.

http://www.scielo.br/pdf/rbs/v25n1/19625.pdf http://dx.doi.org/10.1590/S0101-31222003000100004

[3] Alves, C.Z. and De Sá, M.E. (2009) Teste de condutividade elétrica na avaliação do vigor de sementes de rúcula. Revista Brasileira de Sementes, Londrina, 31, 203-215. http://dx.doi.org/10.1590/S0101-31222009000100023

[4] Kikute, A.L. and Marcos Filho, J. (2012) Testes de vigor em sementes de alface. Revista Horticultura Brasileira, 30, 44-50. http://www.scielo.br/pdf/hb/v30n1/v30n1a08.pdf

[5] Perry, D.A. (1981) Report of the Vigour Test Committee 1977-1980. Seed Technology, Zurich, 9, 115-126.

[6] Spinola, M.C.M., Caliari, M.F., Martins, L. and Tessaroli Neto, J. (1998) Comparação entre métodos para avaliação do vigor de sementes de cenoura. Revista Brasileira de Sementes, Brasília, 20, 301-395. http://www.abrates.org.br/revista/artigos/1998/v20n2/artigo10.pdf

[7] Silva, J.B. and Vieira, R.D. (2006) Avaliação do potencial fisiológico de sementes de beterraba. Revista Brasileira de Sementes, Pelotas, 28, 128-134. http://dx.doi.org/10.1590/S0101-31222006000200017

[8] Matthews, S. (1980) Controlled Deterioration: A New Vigour Test for Crop Seeds. In: Habblethwait, P.D., Ed., Seed Production, Butterworths, London, 647-660.

[9] Freitas, R.A. and Nascimento, W.M. (2006) Teste de envelhecimento acelerado em sementes de lentilha. Revista Brasileira de Sementes, Pelotas, 28, 59-63. http://dx.doi.org/10.1590/S0101-31222006000300009

[10] Malone, P.F.V.deA., Villela, F.A. and Mauch, C.R. (2006) Potencial fisiológico de sementes de mogando e desempenho das plantas no campo. Revista Brasileira de Sementes, Pelotas, 30, 123-129. http://www.scielo.br/scielo.php?script=sci_nlinks\&ref=000109\&pid=S0102-0536201200010002400022\&lng=en

[11] Brasil. Ministério da Agricultura e da Reforma Agrária (2009) Regras para análise de sementes. SNDA/DNDV/CLAV, Brasília, 398p.

[12] Marcos Filho, J. (1999) Teste de envelhecimento acelerado. In: Krzyzanowski, F.C., Vieira, R.D. and França Neto, J.B., Eds., Vigor de sementes: Conceitos e testes, ABRATES, Londrina, Cap.3, 1-24.

[13] ianhua, Z. and Mcdonald, M.B. (1996) The Satured Salt Accelerated Aging Test for Small Seeds Crops. Seed Science and Technology, Zurich, 25, 123-131.

[14] Salisbury, F.B. and Ross, C.W. (1982) Plant Physiology. 4th Edition, Wadsworth, Belmont, 682p.

[15] Marcos Filho, J. (2005) Fisiologia de sementes de plantas cultivadas. FEALQ, Piracicaba, 405p. 
[16] Ávila, P.F.V., Villela, F.A. and Ávila, M.S.V. (2006) Teste de envelhecimento acelerado para avaliação do potencial fisiológico de sementes de rabanete. Revista Brasileira de Sementes, 28, 52-58. http://www.scielo.br/pdf/rbs/v28n3/08.pdf http://dx.doi.org/10.1590/S0101-31222006000300008

[17] Tunes, L.M., Pedroso, D.C., Barbieri, A.P.P., Conceição, G.M., Roething, E., Muniz, M.F.B. and Barros, A.C.S.A. (2011) Envelhecimento acelerado modificado para sementes de coentro (Coriandrum sativumL.) e sua correlação com outros testes de vigor. Revista Brasileira de Biociências, Porto Alegre, 9, 12-17. http://www.ufrgs.br/seerbio/ojs/index.php/rbb/article/view/1645

[18] Martins, C.C., Martinelli-Seneme, A., Castro, M.M., Nakagawa, J. and Cavariani, C. (2002) Comparação entre métodos para avaliação do vigor de lotes de sementes de couve-brocolos (Brassica oleracea L. var.italica PLENK). Revista Brasileira de Sementes. Londrina, 24, 96-101. http://www.scielo.br/pdf/rbs/v24n2/v24n2a16.pdf

[19] Lopes, M.M., Sader, R., Paiva, A.S. and Fernandes, A.C. (2010) Teste de envelhecimento acelerado em sementes de Quiabo. Bioscience Journal, 26, 491-501. http://www.seer.ufu.br/index.php/biosciencejournal/article/view/7126/5121

[20] Barbosa, R.M., Costa, D.S. and De Sá, M.E. (2011) Envelhecimento acelerado de sementes de espécies oleráceas. Pesquisa Agropecuária Tropical, Goiânia, 41, 328-335. http://www.revistas.ufg.br/index.php/pat/article/view/9738/9484

[21] Olivo, F., De Tunes, L.M., Cantos, A., Marini, N., Bertan, I. and Peske, S.T. (2008) Aplicabilidade de diferentes testes de vigor na avaliação da qualidade fisiológica de sementes de aveia (Avena sativa L.). Reunião da comissão brasileira de Pesquisa de aveia. Pelotas. Anais... Pelotas: UFPEL, 315-318.

[22] Santos, F., Trani, P.E., Medina, P.F. and Paris, J.J.D. (2011) Teste de envelhecimento acelerado para avaliação da qualidade de sementes de alface e almeirão. Revista Brasileira de Sementes, Londrina, 33, 322-323. http://www.scielo.br/pdf/rbs/v33n2/15.pdf

[23] Tunes, L.M., Tavares, L.C., Rufino, C.A., Vieira, J.F., Acunha, T.S., Barros, A.C.S.A. and Muniz, M.F.B. (2011) Accelerated Aging of Onion Seeds (Allium cepa L.) Submitted to Saturated Salt Solution. Revista Colombiana de Ciências Hortícolas, 5, 244-250.

http://virtual.uptc.edu.co/revistas2013f/index.php/ciencias_horticolas/article/viewFile/1264/1260

\section{List of Abbreviations}

\section{Germination-GERM}

First germination count $-1^{\circ} \mathrm{CONT}$

Seedling emergence-EP

Standard Accelerated Aging Test—SAAT

Saturated Salt Accelerated Aging-SatSAA

Salt Solution Accelerated Aging-SSAA 